\title{
A HATALOM KONSZOLIDÁCIÓJA
}

\author{
Rajnai Gergely \\ (Budapesti Corvinus Egyetem)
}

\begin{abstract}
ÖSSZEFOGLALÓ
A tanulmány a hatalmi konszolidáció fogalmát járja körül. Ez a fogalom számos olyan politikai jelenséget ír le, amellyel a politikatudomány több különböző ága foglalkozott érintőlegesen, de a konszolidáció fogalmára egyik sem fókuszált; a jelenségeket eddig még nem sikerült átfogó keretrendszerbe foglalni. Ez a tanulmány a fogalom konceptualizációjával foglalkozik; a hatalmi konszolidáció definícióját adja meg úgy, hogy azt a demokratikus konszolidáció alaposan körüljárt koncepciójával állítja párhuzamba. Az általános definíció mellett a konszolidáció különböző típusait (negatív, semleges és pozitív konszolidáció; a hatalom beágyazása) is körülírja, azokat példákkal illusztrálva, és bemutatva azt is, hogy a különböző konszolidációtípusok miként viszonyulnak egymáshoz. Végül a demokrácia és a hatalmi konszolidáció viszonyát járja körül a tanulmány, megállapítva, hogy a hatalmi konszolidáció minden rendszerben előfordul, de bizonyos típusai összeegyeztethetetlenek a liberális demokrácia alapelveivel.
\end{abstract}

Kulcsszavak: demokrácia • hatalom • konszolidáció - politikaelmélet

\section{BEVEZETÉS}

Írásom témája az elmúlt években komoly figyelmet kapott mind a politikai sajtó, mind különböző tudományágak részéről. A hírekben gyakran olvashattunk olyan politikusokról, akik magukhoz ragadták a hatalmat (power grab) több országban is; ez a jelenség ráadásul a legkülönbözőbb politikai rendszerekben egyaránt jelentkezett. Például a hibrid rezsimet vezető török elnök és az amerikai Republikánus Párt egyes intézkedéseire egyaránt használták a kifejezést. ${ }^{1}$ Rengeteg ehhez hasonló történetről olvashattunk a legkülönbözőbb politikai berendezkedésú országokból, a téma tehát a politikai média homlokterében áll.

Ezen érdeklődés ellenére a fogalom politikaelméleti leírása eddig hiányos maradt; a kifejezést tudományos és újságcikkekben is használták anélkül, hogy közelebbről meghatározták volna. A tanulmány célja ezért az, hogy a hatalom konszolidációját definiálja, és leírja a múködését. Ehhez szükséges körülhatárolni azt, hogy mely jelenségek tartoznak a hatalmi konszolidációhoz, ezek miként tipizálhatók, a különböző típusoknak milyen jellemzőik vannak. A típusok 
leírásához a demokratikus konszolidációval állított párhuzam ad támpontot a tanulmányban; ez a párhuzam teszi lehetővé, hogy a hatalmi konszolidáció új fogalmi keretet kapjon, ezáltal a gyakran használt, de valódi tartalom nélkül maradt kifejezés használható keretrendszerbe kerül, amelynek segítségével a hatalmi konszolidáció különböző eseteit könnyebb lesz megérteni és egymással összevetni.

A tanulmány három nagyobb részre tagolódik: először a hatalmi konszolidáció definíciója mellett áttekintem a vele rokon fogalmak irodalmát és viszonyát a tanulmány központi fogalmával, majd a demokratikus konszolidációval állított párhuzam segítségével leírom, valamint példákkal illusztrálom a hatalmi konszolidáció típusait és a típusok jellemzőit, végül a hatalmi konszolidáció és a demokrácia viszonyát tekintem át.

\section{A HATALOM KONSZOLIDÁCIÓJA}

A hatalmi konszolidáció kifejezést gyakran olvashatjuk tudományos vagy publicisztikai írásokban, ennek ellenére a politikatudomány nem tárgyalta a fogalmat kellő alapossággal. Ezért mindenekelőtt a hatalmi konszolidáció rövid, tág definíciójára van szükség. Ehhez először a hatalmat szükséges körülírni, hiszen ez a fogalom is számtalan eltérő definícióval rendelkezik. Jelen tanulmány Dahl pluralista megközelítését tekinti kiindulási alapnak, ami a hatalom szúk értelmezését adja: a hatalom egy képesség, aminek birtokosa képes befolyásolni a közpolitika alakítását olyan esetekben, amikor a közpolitikai döntéssel kapcsolatban vita, konfliktus tapasztalható (Dahl, 1961: 330.). A hatalom ebben az értelemben szigorúan politikai, formálisan is megragadható fogalom, a hatalom ennél tágabb értelmezéseivel ebben az írásban nem kívánok foglalkozni.

Dahl szúk értelemben definiált politikaihatalom-koncepciója több szempontból is hasznos a hatalmi konszolidáció definiálásához és tipizálásához. Egyrészt, mivel a tanulmány középpontjában egy új fogalom áll (bár a fogalom által leírt jelenségekkel a társadalomtudomány foglalkozott már), ezért először egy szúk definícióra és tipológiára törekszik, hogy a lehető legvilágosabb struktúrát tudja felvázolni, ezt pedig egy szúk hatalomdefiníció teszi lehetôvé. Tágabb, a szúk politikaihatalom-fogalmat túlhaladó hatalomkoncepció használata esetén az értelmezés, a definíció és a tipológia jóval bonyolultabbá válna, nehezebb lenne kompakt leírást adni a hatalmi konszolidációhoz tartozó jelenségekről és azok jellemzőiről. A tanulmányban bevezetett új fogalom így is rendkívül tág, sok különböző jelenséget foglal magában, a kiterjedtebb hatalomdefiníció tovább szaporítaná ezek számát, csökkentve az áttekinthetőséget. A hatalmi konszolidáció fogalma ettől függetlenül összeegyeztethető más hatalomfelfogásokkal is, de jelen tanulmány alapjaként egy szúk hatalomdefiníció szolgál az áttekinthetőség érdekében. Később más, akár tágabb hatalom- 
felfogások alapján átalakítható lehet a tanulmány definíciója és tipológiája, ebbőll a szempontból ez az írás kiindulópontként szolgál.

A szúk hatalomdefiníciók közül azért Dahlé a legmegfelelőbb, mert az így definiált hatalmat viszonylag könnyen mérhetővé lehet tenni, és így ellenőrizhető, hogy beszélhetünk-e sikeres konszolidációról, vagy nem. Ez azért fontos, mert az új fogalom legitimitását növelheti, ha empirikusan igazolni lehet a konszolidáció hatékonyságát. A fogalom így nem csupán elméletileg, hanem empirikusan is értelmezhető lehet. Eltérő hatalomdefiníció választása esetén erre kevésbé nyílna lehetőség a későbbiekben.

Hatalmi konszolidációról ebben az értelemben akkor beszélünk, ha egy politikai aktor, aki hatalom birtokában van, arra használja pozícióját, hogy hosszú távú hatalmát növelje, vagy legalább megőrizze azon a szinten, ami már rendelkezésére áll. Ahhoz tehát, hogy egy jelenséget hatalmi konszolidációnak ítéljünk, a következőkre van szükség:

1. A konszolidáló aktor rendelkezik bizonyos mennyiségú hatalommal.

2. Tudatos politikai cselekvés a konszolidáló aktortól (legyen az személy vagy csoport).

3. Ez a cselekvés a már meglévő hatalom felhasználásával történik.

4. Ez a cselekvés arra irányul, hogy az aktor hosszú távú hatalma növekedjen vagy ne csökkenjen.

Hatalmi konszolidációról csak mind a négy feltétel teljesülése esetén beszélhetünk. Így a hatalom nélküli szereplők nem képesek hatalmi konszolidációra (mert nincs mit konszolidálniuk), ahogyan intézmények sem (mert nem személy vagy csoport hajtja végre a konszolidációt). Ezenfelül a hatalom nem konszolidálhatja önmagát, hanem a konszolidációt tudatos aktorok végzik kifejezetten konszolidációs céllal (bár lehetnek egyéb céljaik is az intézkedésekkel, de egyértelmú cél a hatalom növelése vagy megtartása); a hatalom konszolidációja sosem történik véletlenül. Végül fontos kiemelni, hogy a konszolidáció a hosszú távú hatalomra irányul, az olyan lépések tehát, amelyek rövid távon hatalomnövekedést eredményeznek, de a hosszú távú hatalmat nem befolyásolják vagy csökkentik, nem tekinthetők hatalmi konszolidációnak. Gyakran találkozhatunk olyan lépésekkel, amelyek mind a rövid, mind a hosszú távú hatalmat növelik, ezek természetesen hatalmi konszolidációnak minősülnek.

\section{A HATALOM KONSZOLIDÁCIÓJÁVAL ROKONÍTHATÓ FOGALMAK}

A fentebb megadott definíció rokonítható a hatalmi konszolidáció néven definiált szociológiai fogalommal, amelyet Turner (2004) írt le. Nála a fogalom akkor kerül elő, amikor a társadalomban megtalálható négy alapvető erőt írja le; ezek közül az egyik a hatalom. Turner előbb azonosítja a hatalom négy különböző forrását, majd megállapítja, hogy „a hatalom konszolidációja a négy 
forrás együttes mobilizációját igényli" (Turner, 2004: 232.). Így a hatalom konszolidációja egyben a hatalom használatának egy meghatározott módja is, ebben a vonatkozásban Turner definíciója eltér az ebben a tanulmányban használttól.

Turner ezután a konszolidációt szembeállítja a centralizációval; ez utóbbi akkor következik be, ha "a döntéshozás és a parancskiadás a populáció egy viszonylag kis létszámú csoportjának kezében összpontosul" (uo.). Véleménye szerint a konszolidáció elősegíti a centralizációt, de a centralizáció ritkán jelent konszolidációt, ugyanis a centralizáció folyamata jellemzően egy vagy két forrásra összpontosul. Turner centralizációfogalma közel áll jelen tanulmány konszolidációdefiníciójához, de semmiképp sem azonos vele. Az ebben a tanulmányban leírt hatalmi konszolidáció gyakorta centralizálja a hatalmat, de előfordulhat, hogy ellenkező folyamat zajlik le: elképzelhető, hogy a döntéshozatali folyamatba új rétegeket bevonva képes hosszú távon növelni a hatalmát egy politikai aktor (pl. egy politikus a demokrácia kiterjesztésével növelheti a befolyását, ha úgy látja, hogy nézeteit támogatja a többség).

Turner nincs egyedül azzal, hogy a konszolidáció és a centralizáció fogalmát rokonítja, történészek és szociológusok egész sora írja le a hatalom konszolidációját egyfajta centralizációként. Charles Tilly (1975) az államhatalom konszolidációjaként írja le azt a folyamatot, ami 1500 után Európában zajlott le, és amelynek során a modern államok kialakultak, miközben magukhoz ragadták a korábban különböző kisebb csoportok által birtokolt erőszak-monopóliumot. Michael Mann is erről a folyamatról beszél, amikor a hatalmi konszolidációt definiálja. Szerinte ebben a folyamatban a lényegi elem az infrastrukturális hatalom kiépítése és növelése volt, azaz „az állam azon képességének javítása, hogy politikai döntéseit végre tudja hajtani területének egészén" (Mann, 1984: 113.). Jelen tanulmány nézőpontjából azonban ez a folyamat sem minősül feltétlenül konszolidációnak, ugyanis az írás fókusza az egyes aktorok hatalmának növekedésén van, Mann pedig egy intézmény (az állam) hatalmáról értekezik. A szociológusok jellemzően intézmények hatalmával, az azokon keresztül kiépített és azokon belül kiépülő struktúrákkal, a hatalom saját mozgásával foglalkoznak, ebben a tanulmányban viszont konkrét politikai aktorok (politikusok, pártok) hatalmi konszolidációjáról, aktív politikai cselekvők személyes tevékenységéről van szó (bár a kettő gyakran egybeeshet, alapvetően eltérő fogalmakról van szó). Ezenfelül a tanulmány (szemben a történettudománnyal) nem nyúl vissza a régmúltba, a fogalom, amelyet körülírok, olyan államokban zajlik le, ahol az államhatalom már megszilárdult, és nem premodern, törzsi viszonyok uralkodnak, tehát az itt definiált hatalmi konszolidációra a szociológia által leírt hatalmi konszolidáció után kerülhet sor. Ennélfogva sem a szociológia, sem a történettudomány által leírt hatalmi konszolidáció vagy hatalmi centralizáció nem képes a tanulmány fogalmi keretét megadni. 
A hatalom közgazdaságtani leírásának azon iránya, amely a hatalmat a pénzhez hasonlítja (pl. Parsons, 1963; Deutsch, 1968), szintén rokonítható a tanulmány kulcsfogalmával. Ebben a felfogásban a hatalmi konszolidáció a hatalom befektetésének feleltethetô meg: ilyenkor a hatalom birtokosa korlátozza magát, hogy a későbbiekben még több hatalommal rendelkezzen (Deutsch, 1968: 44-46.). Ez az értelmezés ugyan rendkívül közel áll az ebben a tanulmányban használt definícióhoz, mégsem használható a befektetés-analógia a hatalmi konszolidáció helyett. Ennek oka, hogy egyrészt ennek az elméletnek a hatalommal kapcsolatos nézőpontja némileg eltér az itt használttól (a hatalom és a pénz közötti hasonlóság nem része az itt használt megközelítésnek), másrészt pedig az analógia magában hordoz egy implicit állítást, ami sok esetben nem állja meg a helyét. Mégpedig azt, hogy a hosszú távú hatalom megtartásához vagy növeléséhez szükséges a rövidtávú hatalom csökkentése, azaz a hatalommal bíró szereplő korlátozza magát azért, hogy később is hatalommal bírjon. Ez sok esetben igaz lehet, de a konszolidációnak nem feltétele, hogy a konszolidáló aktor ne éljen lehetőségeivel a jelenben. Sőt, elképzelhető, hogy éppen a rövidtávú hatalmi lehetőségek teljes kiaknázása vezet a hosszú távú hatalom növeléséhez (pl. egy képviselő korrupt lesz, így elnyerve gazdasági csoportok támogatását, akik segítségével újraválasztják). Ezért a befektetésanalógia hiába áll közel a konszolidáció fogalmához, mégis tévútra vezetne a használata.

A jogtudomány a hatalmi konszolidáció jogi, jellemzően az alkotmányra irányuló formáira koncentrált az elmúlt években. Ennek kapcsán alkotta meg Landau (2013) az alkotmányos visszaélés (abusive contitutionalism) fogalmát. Az alkotmányos visszaélés azt a folyamatot takarja, amikor a jogalkotó átalakítja a jogrendet (rendszerint a jogrend alkotmányos alapjait) - nem azért, mert erre demokratikus igény mutatkozott, vagy a korábbi jogrendszer olyan problémákat eredményezett, amelyeket e reformok tudnának megoldani, hanem pusztán azért, hogy az újonnan kialakult rendszerben az ő hatalma növekedjen. Landau ugyan elsősorban demokráciákat és hibrid rezsimeket elemez cikkében, de a jogtudomány sokkal többet foglalkozott az autoriter rendszerekbeli alkotmányos visszaélésekkel. Tushnet (2015) autoriter alkotmányosságról írt cikkében tárgyalja azt, hogy a diktatúrák fennmaradásához miként járulhat hozzá az alkotmányos szabályok alakítása, Ginsburg (2014) pedig több szempontból és több példán keresztül azt mutatja be, hogy a hatalom megszerzése után az alkotmányos rend stabilizálhatja az újonnan megszerzett pozíciókat. Ez a jelenség nagyon közel áll a tanulmány központi fogalmához, ám politikai helyett jogi fókusszal bír, az alkotmányos visszaélés esetei azonban fontosak a hatalmi konszolidáció megértéséhez.

A politikatudomány az elmúlt években világszerte megjelenő hatalmi konszolidációs esetekre elsősorban rengeteg esettanulmánnyal reagált, ám viszonylag ritka az olyan kísérlet, amely ezeket átfogó fogalmi keretbe foglalta 
volna. Kivételt képeznek a fiatal, törékeny demokráciákkal foglalkozó tudósok, akik körében fokozott érdeklődésre tart számot az a gyakori jelenség, amikor ezen országok politikai vezetői a liberális demokrácia szabályaival ellentétes módon próbálják megerősíteni a hatalmukat. A hatalmi konszolidáció eredményeképpen ezen ifjú demokráciák közül több is hiányossá (defective) vált, bizonyos szempontok alapján elveszítették demokratikus jellegüket, így választási autokráciákká alakultak (Schedler, 2006). A választási autokráciákban a demokratikus intézmények ugyan a felszínen fennmaradnak, de nincs reális lehetőség a kormányzó párt vagy politikus demokratikus leváltására, így, bár több szempontból demokráciák maradnak, semmiképp sem lehet őket liberális demokráciáknak nevezni, és egy lapon említeni a nyugati, konszolidált rendszerekkel. Ehhez nagyon hasonlóak és szintén a hatalmi konszolidáció eseteinek bő tárházát nyújtják a Levitsky és Way (2010) által leírt kompetitív autoriter rendszerek is. Cheeseman és szerzőtársai (2017) pedig a közelmúlt ghánai választásait elemezve azt állapítják meg, hogy a fiatal demokráciákban az inkumbensek gyakran a demokratikus szabályokat változtatják meg hatalmuk megtartása érdekében; az inkumbens hatás ezért kiemelkedően erős ezekben az országokban.

Más esettanulmányok arra mutatnak rá, hogy az elmúlt években globális jelenséggé vált prezidencializáció (Poguntke-Webb, 2005) több országban is az opportunista politikai aktorok hatalmának növekedését eredményezte. Mulgan (2018) azt a folyamatot írja le, ahogy Abe Shinzo japán miniszterelnök a prezidencializációt kihasználva előbb pártján belül erősítette meg pozícióját, majd ezt a hatalmat felhasználva a japán politikát is egyre inkább dominálta. Tanasescu (2014) Oroszország és Románia példáját felhasználva arra mutat rá, hogy félelnöki rendszerekben, ahol a prezidencializáció folyamata erősebb lehet, mint parlamentáris berendezkedés esetén, ezt egyes szereplők hatékonyan használták fel arra, hogy hatalmukat kiterjesszék olyan területekre, amikre az alkotmányos rendszer alapján korábban nem lett volna lehetőségük.

Többen arra hívták fel a figyelmet, hogy bizonyos politikai szereplők gazdasági hálót létrehozva tudják stabilizálni hatalmi pozíciójukat, így nemcsak a szúk értelemben vett politikai, hanem a gazdasági szférát is figyelembe kell venni a hatalmi konszolidáció vizsgálata során. Lanskoy és Myles-Primakoff (2018) például azt mutatják be, hogy Vlagyimir Putyin azért tudja dominálni az orosz politikát, mert egy olyan gazdasági rendszert hozott létre, amelyben tôle függ az összes gazdasági kulcsszereplő, így hatalmának megőrzése és kiterjesztése érdekében szinte korlátlanul tud gazdasági erőforrásokat is mozgósítani.

Ezek a politikatudományi leírások egytől egyig a kortárs hatalmi konszolidáció jelenségeit tárgyalják valamilyen speciális szemüvegen keresztül (alkotmányos rendszer, fiatal demokráciák, prezidencializáció, gazdasági és hatalmi struktúra összefonódása), de egyik sem ad átfogó áttekintést a fogalom- 
ról. Arra alkalmasak, hogy alapos esettanulmányok segítségével a hatalmi konszolidáció különböző típusaira példát szolgáltassanak, de ezek az esettanulmányok is jobban érthetővé válnak, ha a hatalmi konszolidáció általános leírásának és a későbbiekben leírt tipológiájának ismeretében tekintünk rájuk.

\section{DEMOKRATIKUS KONSZOLIDÁCIÓ}

A tanulmányban használt definíció tehát csupán rokonítható már leírt társadalomtudományi fogalmakkal. Egy másik, látszólag kevéssé kapcsolódó fogalomra van szükség a hatalmi konszolidáció alaposabb körülírásához; mégpedig a demokratikus konszolidációra. A demokratizáció harmadik hulláma a demokratikus konszolidációt a politikatudomány egyik leggyakrabban használt fogalmává tette. A konszolidációról szóló irodalom szerint akkor konszolidált egy demokrácia, ha valószínútlen, hogy összeomlik (Schedler, 2001: 66.), vagy más szavakkal, egy konszolidált demokráciában a demokrácia alternatíva nélkül marad (Linz-Stepan, 1996: 5.).

Miután a demokratikus konszolidáció igen széles körben használt fogalommá vált, tartalma némileg kiüresedett, ugyanis ahányan írtak a fogalomról, annyi új, némileg eltérő definíció született. Schedler (1998) a konszolidáció öt alapvető jelentését különbözteti meg, amelyet három nagyobb kategóriába sorol. Az első típus, a negatí konszolidáció két altípusa a diktatórikus rezsim visszatérésének megakadályozása, valamint a demokratikus minőség eróziójának megelőzése. Ez a konszolidáció legalapvetőbb formája, amely biztosítja, hogy a már elért demokratikus vívmányok fennmaradjanak, és az új rendszer legalább az aktuális (akár hiányos) formáját megőrizze; nem vedlik át kevésbé demokratikus formába. Schedler (1998: 96) szerint a negatív konszolidáció elsőszámú eleme „a [demokrácia iránt] el nem kötelezett szereplők semlegesítése vagy átállítása". Ez a típus áll a legközelebb a fentebb említett definíciókhoz.

Amikor bizonyos alapvető demokratikus intézmények kialakultak, megkezdődhet a semleges konszolidáció (más néven a demokrácia megszervezése). A demokrácia megszervezése különböző folyamatok összessége, amelyek a politikai rendszert ellenállóbbá teszik, és előkészítik a demokratikus minőség további javítására. Mindeközben azonban a rendszer nem alakul át sem demokratikusabb, sem diktatórikusabb rezsimmé, ugyanabba a típusba tartozik, mint korábban.

Végül a harmadik típus, a pozitív konszolidáció a demokrácia fejlesztését (mélyítését, befejezését) jelenti. A demokráciáknak számtalan altípusa van (választási, liberális, illiberális, delegatív, fejlett stb.); az egyik altípusból a másikba eljutni (amennyiben az új altípus a demokráciaelmélet alapján jobb és stabilabb) pozitív konszolidáció segítségével lehetséges. Ez a fajta konszolidáció nagyobb kihívás, mint a negatív, és általában hosszabb időt is igényel, mint 
néhány formális intézmény kialakítása; általában az informális intézmények (pl. civilszervezetek, demokratikus kultúra) kialakítása és terjesztése tartozik ide.

A konszolidáció e három főbb típusa mellett a politikatudomány a konszolidációval rokonítható, nagyon hasonló jelentéssel bíró fogalmakat is alkotott. Az egyik ilyen és a hatalmi konszolidáció szempontjából sem érdektelen fogalom a beágyazottság. Merkel (2004) szerint a beágyazottság a demokratizáció egyik kulcsfogalma: a beágyazott demokráciák kevésbé sérülékenyek és jellemzően demokratikusan fejlettebbek, mint a kevésbé beágyazott rendszerek. A demokrácia beágyazása hasonlít a semleges konszolidációhoz, bár a negatív és pozitív konszolidáció elemei is felfedezhetők benne. A belső beágyazódás során a liberális demokrácia különböző elemeit egy olyan rendszerbe helyezik, amelyben azok interdependenssé válnak, így a demokrácia csak úgy sebezhető, ha minden elemét egyszerre erodálják, ami nehezebb lehet, mint az egyes elemeket külön-külön gyengíteni. A külső beágyazottság Merkel szerint még a belsőnél is fontosabb szerepet tölt be. A gazdasági körülmények javítása, a demokráciát támogató civil társadalom erősitése és az új demokrácia integrációja a demokratikus nemzetközi közösségbe mind fontos elemei a demokrácia megtartásának és fejlesztésének. Ezek a folyamatok a szigorú értelemben vett demokratikus intézményekhez szorosan nem kapcsolódnak, de létfontosságúak az azok fenntartásához alapvetően szükséges külső környezet kialakításához. A beágyazottság tehát a konszolidáció része és előfeltétele is lehet.

\section{A HATALMI ÉS A DEMOKRATIKUS KONSZOLIDÁCIÓ HASONLÓSÁGA}

A fent röviden összefoglalt tipológia a hatalmi konszolidáció esetében is használható. Ez azért lehetséges, mert a kétféle konszolidáció között sok hasonlóság van: mindkét fogalom egy már meglévő dolog hosszú távú megőrzését és/ vagy növelését, javítását, mélyítését írja le, és mindkét esetben ez a dolog kívánatos azoknak, akik birtokolják vagy megalkották, ezért céljuk folyamatosan megőrizni, javítani és növelni; ezért írja Schedler (1998: 95.) azt, hogy a konszolidáció egy „teleologikus fogalom”. Mindkét esetben a megőrzés vagy növelés tárgya (azaz a demokrácia és a hatalom) valamilyen korlátozott, tökéletlen, félkész formában jön létre először, és ezt követően indulhat el a konszolidáció folyamata. Egy hatalommal nem bíró szereplő nem kezdhet hatalmi konszolidációba akkor sem, ha olyan cselekedeteket hajt végre, amelyek hoszszú távú hatalmát egyértelmúen növelik, hiszen a fentebb megadott definíció alapján először valamilyen hatalommal kell rendelkeznie, és éppen ezt az (aktor szerint korlátozott, tehát növelendő) hatalmat használja arra, hogy hosszú távú hatalmát megőrizze vagy növelje. Hasonlóképpen a demokratikus konszolidáció sem kezdhető meg egy autoriter rezsimben, akkor sem, ha valamely sze- 
replő cselekedeteivel a demokratikus intézmények jövőbeli stabilitását vagy minőségét javítja. Például egy diktatúrában az illegális, demokráciát pártoló sajtót terjesztő személyek és csoportok nem a konszolidáció, hanem a kiépítés folyamatát segítik, hiszen a konszolidáció megkezdéséhez szükséges a demokrácia minimális kereteinek megléte. Ezek a hasonlóságok lehetôvé teszik a demokratikus konszolidáció tipológiájának adaptációját a hatalmi konszolidáció esetére.

A demokratikus konszolidáció fentebb idézett két rövid definíciója rendkívül hasonló, ám ha mélyebben megvizsgáljuk őket, van közöttük eltérés, ami eltérő következményeket eredményez. A demokratikus konszolidáció esetében ez kevésbé feltûnő, mert az alternatív államformák pártolóinak visszaszorítása (a demokrácia alternatíva nélkül marad), valamint a demokrácia összeomlásának megakadályozása egymást erősítő elemek. A hatalmi konszolidáció esetében azonban a két definíció két különböző jelenséget, két különböző folyamatot ír le. Ha egy politikai aktor hatalma stabillá vált, az nem jelenti azt, hogy a hatalomnak nem lehetnek alternatív birtokosai. A hatalom felosztható; még ha a hatalom komoly része koncentrálódik is egy aktornál, elképzelhetö, hogy egy választás vagy politikai válság eredményeképp más aktorok is részesülnek a hatalomból a jövőben.

A demokrácia és a hatalom különböző természete tehát azt eredményezi, hogy a konszolidáció kétféle definíciója nem cserélhető fel a hatalmi konszolidáció esetén: hatalmi konszolidációról beszélünk akkor is, amikor egy aktor a saját hatalmát stabilizálja anélkül, hogy riválisait kizárná a politikai versenyből (vagy legalábbis korlátozná a részvételüket), és akkor is, ha kifejezetten korlátozza őket. Érdemes viszont a kettőt megkülönböztetni egymástól. Előbbi akár egy liberális demokráciában is előfordulhat, akár azért, mert a hatalomban lévő aktor hatékonyan kormányoz, akár azért, mert ellenfelei alkalmatlanok, míg utóbbi esetben a demokratikus játékszabályok áthágásáról beszélhetünk (a demokrácia és a hatalmi konszolidáció kapcsolatáról a későbbiekben lesz még szó).

\section{NEGATÍV KONSZOLIDÁCIÓ}

A hatalmi konszolidációt a hasonlóságok miatt a demokratikus konszolidáció mintájára három nagy típusra lehet felosztani: negatív, pozitív és semleges konszolidációra, ezeken belül pedig altípusokat lehet megkülönböztetni.

A negatív konszolidáció esetében a hatalmat birtokló aktor célja hatalmának hosszú távú megőrzése, stabilizálása. Demokratikus körülmények között ez jellemzően azt jelenti, hogy hatalmi pozícióját arra használja fel, hogy az elkövetkezendő választásokon sikeresen szerepeljen, és hatalomban maradjon. Egy versengő rendszer logikája szerint éppen ez az igény fogja jó kormány- 
zásra késztetni a kormányon lévő erőket: amennyiben jól kormányoznak, a választók elégedettek lesznek teljesítményükkel, és hatalomban tartják őket (feltételezve, hogy a választók legfőbb szempontja politikai preferenciáik meghatározásában a kormányzati teljesítmény, és azt is, hogy a kormányerők fő célja a hatalomban maradás, azaz a negatív konszolidáció). Ebben az esetben nem az ellenfelek korlátozásáról, hanem pusztán egy olyan környezet megteremtéséről van szó, amelyben a jövőbeli választásokon a hatalmon lévők esélyei jók maradnak a hatalom megtartására (ezt írja le a Friedrich-törvény [Friedrich, 1963: 203.]). Ez a hatalom megórzése.

Erre a folyamatra számtalan példát találunk a modern politikatörténetben: a Svéd Szociáldemokrata Párt 1932 és 1976 között nem veszített el egyetlen választást sem; úgy használta fel kormánypozícióját, hogy hosszú távú hatalmát megőrizze. Az országos szintû példák demokráciákban azonban igen ritkák, ez a fajta konszolidáció inkább regionális és helyi szinten gyakori. Az Egyesült Államokban több tagállamban egyik vagy másik nagy párt dominanciája tapasztalható (pl. Utahban 1985 óta megszakítás nélkül a Republikánus Párt irányítja a törvényhozás mindkét kamaráját, és a kormányzó is republikánus). Általános jelenség szinte minden országban, hogy számos kisebb településen nagyon erős az inkumbencia hatása, az újraválasztás szinte automatikussá válik (Magyarországon pl. Veresegyházon). Minél kisebb közösségrôl beszélünk tehát, annál könnyebb megvalósítani ezt a fajta konszolidációt; feltehetően azért, mert ehhez szükséges az ellenfelek gyenge teljesítménye, és míg egy kis közösségben viszonylag kevés alternatív vezető van, nagyobb szinteken már sokkal könnyebben lecserélődik egy esetlegesen alkalmatlan ellenzéki garnitúra, és egy olyan jön a helyére, amely képes megfékezni a hatalmon lévők negatív konszolidációját.

Erre természetesen csak akkor van lehetőség, ha a negatív konszolidáció nem alakul át egy másik altípusba, nevezetesen abba, amely a demokratikus konszolidáció alternatíva nélkül marad definíciójával rokonítható. Az ilyen altípus során a hatalmon lévő aktor kifejezetten arra használja a hatalmát, hogy riválisait ellehetetlenítse, korlátozza, kilépve a demokratikus térből. A negatív konszolidáció ezen altípusa a verseny korlátozása. Amikor tudományos cikkek „"a hatalom konszolidációja” kifejezést használják, jellemzően erről az altípusról beszélnek. Ezek a tanulmányok azt írják le, hogy különböző aktorok hogyan szerezték meg és teljesítették ki hatalmukat antidemokratikus vagy legfeljebb részben demokratikus eszközök segítségével, pl. puccsal, választási csalással vagy a demokratikus intézmények felszámolásával, elérve, hogy hatalomban maradjanak hosszú távon. Ennek az altípusnak eklatáns és gyakran elemzett példája a nácik hatalmának kiépülése az 1930-as évek Németországában (pl. Epstein [1962] kifejezetten hatalmi konszolidációnak nevezi ezt az eseménysorozatot). Hasonló folyamatok zajlottak le Nasszer hatalomra kerülésekor Egyiptomban (ezt Thornhill [2004] írta le konszolidációként), a Gázai 
övezetben 2007 után a Hamász hatalmának kiépülése alatt (ezt Milton-Edwards [2008] azonosította hatalmi konszolidációként), vagy Szíriában Bassár el-Aszad elnökségének első évei során (erről Becker [2006] írt, használva a hatalmi konszolidáció kifejezést), de számtalan más példát lehetne hozni, elsősorban hibrid vagy autokratikus rezsimekből.

Ahogy Schedler (1998: 96.) szerint a demokratikus konszolidáció célja „a hútlen aktorok kiiktatása, semlegesítése vagy átállítása", úgy a negatív hatalmi konszolidáció ezen altípusa esetében is a hangsúly az ellenfelek gyengítésén, megsemmisítésén van. A hútlen aktorok kifejezés a demokrácia esetében azokat takarja, akik hatalomra kerülve a demokráciát leépítenék, és egy autokratikus vagy diktatórikus rendszer visszaállítása a céljuk. Ennélfogva a demokratikus konszolidáció egyik fontos eleme éppen a későbbiekben a negatív hatalmi konszolidáció második, antidemokratikus típusát, a verseny korlátozását megvalósítani tervező szereplők semlegesítése.

\section{POZITÍV KONSZOLIDÁCIÓ}

A hatalom konszolidációjának második nagyobb típusa, a pozitív konszolidáció nehezen elválasztható a negatív konszolidációtól, bármelyik altípusáról is beszéljünk. Ahogy a pozitív demokratikus konszolidáció mélyíti vagy befejezi a demokráciát, úgy a pozitív hatalmi konszolidáció a hatalmon lévó aktor hatalmát növeli, terjeszti ki, mélyíti el. A pozitív konszolidáció általában feltételezi a sikeres negatív konszolidációt. Amikor a hatalmat birtokló szereplő biztosította, hogy hatalmi pozícióit nem veszíti el, akkor kezdheti el a pozitív konszolidációt, kiterjesztve befolyását olyan területekre, amelyeket korábban nem irányított, vagy olyan szintre emelve, amelyen korábban nem állt.

Két különböző altípust lehet itt is megkülönböztetni: az egyik esetében a már meglévő hatalmi területeken beszélhetünk a hatalom növeléséről. Ebben az esetben a konszolidáló aktor (Dahl [1972: 18.] fogalomkészletét használva) hatalmának nagyságát vagy mennyiségét növeli, azaz egy adott politikai területen adott szereplők csoportját nagyobb valószínúséggel tudja meggyőzni arról, hogy azok akaratának megfelelően cselekedjenek. Ez a hatalom mélyítése. Például ha egy politikai szereplő a nemzetbiztonsági döntéseket 50\%ban határozta meg, majd meglévő hatalmi pozícióját felhasználva eléri, hogy a nemzetbiztonsági döntések $60 \%$-ban rajta múljanak, az ebbe az altípusba tartozik.

Amennyiben ugyanez a szereplő, aki korábban kizárólag a nemzetbiztonsági döntésekre bírt befolyással, meglévő hatalmát arra használja, hogy a jövőben pl. a fejlesztési költségvetés egy része felett is ő rendelkezzen, az már a második altípusba tartozik. Ebben az altípusban a konszolidáció célja, hogy a hatalom olyan területekre is elérjen, amelyekre korábban a konszolidáló sze- 
replő nem bírt befolyással. Dahl (1972: 18.) tipológiája szerint ekkor hatalmának hatáskörét és/vagy kiterjedését növeli, azaz új politikai kérdések tekintetében szerez hatalmat, vagy új szereplőket képes befolyásolni. Ez a hatalom kiterjesztése. Természetesen a két altípus könnyen keveredhet egymással: ahogy mélyül a hatalom egy adott területen, úgy kerül kapcsolatba egyre több területtel, és úgy lesz legalábbis közvetett befolyása más területekre. A két altípus tehát szorosan összefügghet, mégis érdemes megkülönböztetnünk őket.

Előfordulhat, hogy vagy negatív konszolidáció kísérlete nélkül, vagy sikertelen negatív konszolidáció után kezd egy aktor pozitív konszolidációba. Ez a konszolidáció természetéből fakad: mivel a konszolidáció a hosszú távú hatalomra, azaz egy jövőbeli, a jelenben pontosan nem ismert jelenségre irányul, a konszolidációs kísérlet sikerességét nem lehet előre megítélni. Ennélfogva a konszolidáló aktor nem lehet biztos konszolidációs kísérletének sikerességében. Ez elbizonytalanítja a konszolidációt, ahogy egyébként a demokratikus konszolidáció esetén sem lehet tudni, hogy a konszolidációnak szánt lépés valóban stabilabb, magasabb minőségú demokráciát eredményez-e a jövőben.

Ez a bizonytalanság eredményezheti azt, hogy egy aktor úgy kezdi meg a pozitív konszolidációt, hogy nincs mögötte sikeres negatív konszolidáció. İgy a pozitív konszolidáció minden bizonnyal sikertelen lesz, hiszen, ha még a meglévő hatalmát sem képes megőrizni, azt növelni sem tudja. A hatalom mélyítése ebben az esetben képtelenség, azonban elméleti lehetőség a hatalom kiterjesztésére még ilyenkor is van: miközben a konszolidáló szereplő visszaszorul egy olyan területen, ahol már volt hatalma, egy másik területen szerezhet befolyást. A konszolidáció azonban olyan eseteket ír le, amikor az aktor a már meglévő hatalmi pozíciója felhasználásával szerez befolyást új területeken, így, ha a meglévő hatalmi pozíció, amelyre az új pozíciók kiépítését alapozta, megszúnik, akkor az újonnan megszerzett hatalmi területeken is instabillá válhat a hatalom. Mégis van példa ilyen esetre, például ha egy párt a parlamenti többségét arra használja, hogy bizonyos közjogi pozíciókat (pl. alkotmánybírói posztok) olyan emberekkel töltsön fel, akik az ő felfogását tükrözik; ennek hatása akkor is érződhet, amikor a többség, amelyre alapozta ezt a kiterjesztést, már elveszett. A hatalom kiterjesztése tehát akkor is sikeresen megvalósítható, ha azt hatékony negatív konszolidáció nem előzte meg, viszont a hatalom mélyítése esetében ez elképzelhetetlen.

A negatív konszolidáció antidemokratikus formája, a verseny korlátozása magában hordozza a pozitív konszolidációt. Azzal, hogy a konszolidáló aktor ellenfeleit semlegesíti, üres hatalmi tereket hoz létre (amelyeket korábban riválisai foglaltak el), és ezeket megpróbálja elfoglalni. Az ilyen típusú negatív konszolidáció célja valójában nem csupán a hatalom megtartása, hanem a hatalom hosszú távú növelése, kiterjesztése is. Például a náci rezsim kiépülésekor a verseny egyre erőteljesebb korlátozásával párhuzamosan a nemzetiszocialista párt, annak intézményei és emberei a politikai és később a hétköznapi 
élet egyre nagyobb szeletében szereztek befolyást. A negatív konszolidáció a pozitív konszolidáció elókészítéseként szolgált; a verseny korlátozása természetszerûleg vonja maga után a hatalom mélyítését és kiterjesztését.

\section{SEMLEGES KONSZOLIDÁCIÓ ÉS A HATALOM BEÁGYAZÁSA}

A semleges konszolidáció, a hatalom konszolidálásának harmadik főbb típusa, nehezebben megfogható, mint a pozitív vagy a negatív konszolidáció, mégis rendkívül fontos jelenségről beszélünk. Ahogyan a demokratikus konszolidáció esetében a semleges konszolidáció a demokrácia megszervezéseként írható le, úgy a hatalom megszervezése kifejezés sem áll messze attól, amit a semleges hatalmi konszolidáció jelent. Bármilyen jól is legyen kialakítva egy hatalmi struktúra, ha hosszú ideig érintetlen marad, könnyen összeomolhat, és ha nem alakítják át, nem lesz egyszerű kiterjeszteni vagy mélyíteni a benne kialakított hatalmat. A hatalomnak folyamatosan alkalmazkodnia kell az állandóan változó külső körülményekhez. Ezek az átalakítások nem kifejezetten a hatalom kiterjesztésére, mélyítésére vagy megőrzésére irányulnak, de azokat elősegítik, vagy azok előfeltételei.

A gyakorlatban a semleges konszolidáció nagyon közel áll a Merkel által bevezetett beágyazottság fogalmához, és altípusai is a beágyazottság tipológiájának segítségével adhatók meg, ezért a két fogalmat szinonimaként kezelem a hatalom esetében. A hatalom belső és külső beágyazottságát érdemes megkülönböztetni. Ha a hatalmi struktúra különböző elemei interdependensek (tehát belsőleg beágyazottak), a hatalom megőrzését jóval egyszerűbb megvalósítani, hiszen a hatalom kevésbé lesz sebezhető - nincs gyenge pontja, mivel a különböző elemek egymástól függnek, egyenként nem lehet őket lebontani, ezáltal a hatalmat nem lehet gyengíteni, csak teljesen megtörni, ami viszont igen nehéz feladat. Például, ahogy Arendt (1951) leírja, a '30-as évek Németországában a náci hatalmi struktúra egyes elemei nagyon szorosan függtek egy központi akarattól, amit a Führer képviselt. Ezért nem lehetett elemenként lebontani a rendszert, hanem az egészet kellett megdönteni, ami hatalmas feladatnak bizonyult, és külső beavatkozás nélkül nem is sikerült.

A külső beágyazottság fontos előfeltétele lehet a hatalmi konszolidációnak. A társadalmi-gazdasági környezet, a civil társadalom és a nemzetközi rendszer egyaránt elősegítheti vagy akár megakadályozhatja a hatalom konszolidációját. Amikor bizonyos valós vagy potenciális befolyással bíró csoportok társadalmi vagy gazdasági érdekeit sérti egy hatalmi struktúra léte vagy annak terjeszkedése, mélyülése, akkor ezen csoportokkal is meg kell birkóznia a konszolidálónak, ami jóval bonyolultabb feladat, mint amikor a társadalmi-gazdasági környezet a hatalmi struktúrának kedvez, és ezek a csoportok támogatják a konszolidációs próbálkozásokat, vagy legalább passzívan tekintenek 
rá. Például egy gazdasági válság jelentősen megnehezíti a konszolidációt a kormány számára, hiszen a lakosság számos csoportja elégedetlen lesz anyagi helyzetével, és ezért szívesebben támogatja a változást ígérő (egyben a hatalmi konszolidációt megakadályozó) erőket. Amennyiben azonban a társadalmi és gazdasági csoportok elégedettek, kevésbé fogják ellenezni a hatalom konszolidációját. Hasonlóan sokat segíthet a konszolidációban, ha a konszolidáló szereplőnek van egy gazdasági hátországa, amelyre támaszkodni tud akár a szakpolitikák kialakításában, akár a választási kampány során.

A nemzetközi beágyazottság szintén kulcsfontosságú szerepet tölt be a hatalmi konszolidációban, különösen kisebb országokban, amelyek kiszolgáltatottak a nagyhatalmaknak. Elég csak a magyar példára gondolni: 1945 után a kommunista hatalmi konszolidáció a Szovjetunió támogatásán nyugodott; a magyar politikai, gazdasági és társadalmi viszonyoktól szinte teljesen függetlenül folyt le, nem volt szükség a tömegek vagy akár a helyi elit támogatására. Amint a keleti blokk összeomlott, az ebbe beágyazott rezsim hatalma is szertefoszlott, és ezután szinte kizárólag olyan pártok versengtek a hatalomért, amelyek hatalmukat Nyugaton próbálták meg beágyazni, az Európai Unióhoz, a NATO-hoz és nyugati nagyhatalmakhoz (Egyesült Államok, Németország) közeledve. Egy Magyarország-méretú ország esetében tehát ez a fajta beágyazottság különösen fontos.

A külső beágyazottság harmadik típusa a beágyazódás a civil társadalomba. A civil szféra természetesen a hatalmi konszolidációt is érintheti negatívan vagy pozitívan, így ide is érdemes beágyazni a hatalmat a konszolidáló aktoroknak. Egyrészt lehetséges a konszolidációt gátolni kívánó civilszervezetek korlátozása vagy meggyőzése. Ehhez negatív (szankciók) vagy pozitív ösztönzőket (kompromisszumok, bizonyos követelések teljesítése) is bevethet a konszolidáló politikai szereplő. Ez azonban még nem ér el kifejezett beágyazottságot, csak azt, hogy az aktív ellenállás visszaszorul. A beágyazottsághoz a konszolidációt támogató szereplővé kell tenni a civil társadalmat, vagy akár a hatalmi struktúrába is be lehet építeni ezt a szférát. Erre a beágyazottságra jó példa az államszocialista hatalmi struktúra, ahol a civil tevékenységet összekapcsolták a hatalom támogatásával (pl. úttörőmozgalom).

\section{DEMOKRÁCIA ÉS HATALMI KONSZOLIDÁCIÓ}

Nem lehet megkerülni a kérdést, hogy a hatalmi konszolidáció milyen viszonyban áll a demokráciával. Egyrészt azért nem, mert a demokratikus konszolidációval állítottam párhuzamba a hatalmi konszolidációt, másrészt pedig azért nem, mert mind a politikatudomány, mind a politikai újságírás alapvetôen egy demokrácia ellen ható jelenséget ért a kifejezés alatt. A legtöbb, a kifejezést használó tudós és újságíró szerint a hatalmi konszolidáció megvalósulása annak 
a jele, hogy az adott ország nem (liberális) demokrácia, hanem diktatúra vagy hibrid rezsim.

Ennek az összefüggésnek van némi alapja, hiszen a modern demokráciák egyik legfontosabb alapelve a hatalmi ágak elválasztása, és többen (pl. Vanhanen, 2000) hangsúlyozzák, hogy a demokrácia egyik kulcsfontosságú jellemzője az, hogy a hatalom nem koncentrálódik kis csoportok kezében, hanem viszonylag egyenlő az eloszlása a különböző csoportok között. Ebből az következik, hogy minél több hatalom kerül egy aktorhoz (a konszolidáció eredményeképpen), annál kevésbé demokratikus az adott rendszer. Amennyiben pedig a különböző hatalmi ágak interdependenssé válnak (belső beágyazottság), a demokrácia egyik alapvető követelménye sérül. Ezek szerint egy jól múködő liberális demokráciában a hatalmi konszolidáció kísérletei sikertelenek, sőt, akár azt is mondhatnánk, hogy elő sem fordulnak, hiszen azok a szereplők, akik hatalmi konszolidációt kísérelnek meg, arra vállalkoznak, hogy gyengítsék vagy lebontsák a liberális demokratikus berendezkedést, ilyen aktorok pedig nem kerülhetnek hatalmi pozícióba egy konszolidált liberális demokráciában, vagy ha mégis, a fékek és ellensúlyok elrettentik a konszolidációs kísérlettől. Ez alapján úgy tûnik, hogy a demokrácia ellentétben áll a hatalmi konszolidációval: egy rendszer vagy teljesen demokratikus, vagy végrehajtható benne a hatalmi konszolidáció.

A kép azonban nem ennyire tiszta, hatalmi konszolidáció minden rendszerben előfordulhat. A különböző típusok bemutatásánál a példákkal szándékosan utaltam mind liberális demokráciákra, mind totális diktatúrákra, mind hibrid rezsimekre: mindben találunk példát sikeres hatalmi konszolidációra. Senki sem vitatkozik azzal, hogy Svédország vagy Németország a liberális demokráciák közé tartoznak, mégis mindkettőben előfordult a hatalmi konszolidáció egyik vagy másik formája. Elsősorban a negatív konszolidáció van jelen a fejlett demokráciákban, ez ugyanis, mivel nem alakítja át alapvetően a hatalmi viszonyokat (a hatalom nem terjed ki új területekre), összeférhet a demokrácia alapelveivel. Amíg a demokratikus játékszabályok által kijelölt hatalmi térben marad a konszolidáló aktor, nem feltétlenül erodálja a demokráciát hatalmának megőrzésével. Ha egy rendszerben akár évtizedekig képes egy politikai szereplő hatalmon maradni, akkor azt néhányan (pl. Golder, 2005) már nem minősítenék demokratikusnak, mert a hatalmon lévők váltakozásaként írják le a demokráciát, és ez nem felel meg ennek a kritériumnak; viszont a legtöbb demokráciadefinícióval összeegyeztethető a negatív konszolidáció. Elég csak Sartori (1976) klasszikus munkájára gondolnunk, aki a hatalmukat negatívan konszolidáló demokratikus pártokat predomináns pártoknak nevezte, és a predomináns pártrendszert, amelyben a győztes kiléte gyakorlatilag a választások előtt megjósolható, a demokratikus pártrendszerek közé sorolja.

A semleges konszolidáció a negatív konszolidációhoz hasonlóan nem terjeszti ki a konszolidáló aktor hatalmát új területekre, így nincs alapvető ellent- 
mondásban a liberális demokráciával. A demokratikus körülmények között megszerzett hatalmat szervezni, folyamatosan átalakítani a változó körülményeknek megfelelően nem feltétlenül mond ellent a liberális demokrácia játékszabályainak, sőt, bizonyos értelemben elvárás ez a politikai szereplőkkel szemben. Az olyan aktor, aki érintetlenül hagyja a hatalmi struktúrát, nem változtat a módszerein, nem reflektál a választók és a külső környezet változó igényeire, így nem is nevezhető tökéletesen demokratikusnak, mert nem reszponzív. A reszponzivitás hiányát elméletileg a választók meg is büntetik, így a hatalom elvesztését vagy legalábbis csökkenését, a negatív konszolidáció ellehetetlenítését eredményezi a negatív konszolidáció hiánya (Friedrich, 1963: 203.). Természetesen előfordulhat, hogy a hatalom szervezése a demokratikus keretek lebontásával vagy erodálásával jár együtt, de a semleges konszolidáció összeegyeztethető a liberális demokrácia akár legszigorúbb alapelveivel is, sőt, demokratikus elvárás a folyamatos adaptáció.

A pozitív konszolidáció a leginkább problematikus konszolidációtípus a liberális demokrácia szempontjából, ugyanis a hatalom növelése, kiterjesztése új területekre a kiszabott alkotmányos kereteket áttörheti, ezáltal megsértve a demokratikus alapelveket, és ha az ilyen lépések nem is szüntetik meg a demokráciát, annak minőségét mindenképpen rontják. Elképzelhető azonban, hogy éppen a hatékony demokratikus múködést segíti elő a pozitív konszolidáció. Gyakran előfordul, hogy a demokratikus intézményrendszer korlátai megbénítják a döntéshozatalt (pl. ha túl sok szereplő bír vétójoggal), és a túl sok fék és ellensúly ellehetetlenítik, hogy a kormány bármit is végrehajtson terveiből, ezzel gátolva a demokratikus folyamatot (a választói akarat érvényesülését). Bizonyos esetekben indokolt lehet egyes korlátok megszüntetése, a vétóval bíró szereplők számának csökkentése a kormányzás hatékonyságának növelése és a volonté générale érvényesülése érdekében, de ezek csak ésszerü kereteken belül folyhatnak le (pl. riválisok beleegyezésével), hogy ne csökkentsék a demokrácia minőségét. Egy-egy ilyen intézkedés növeli a hatalmon lévők mozgásterét, és így pozitív konszolidációnak tekinthető, mégis belefér a liberális demokrácia kereteibe.

A hatalom külső beágyazása is összeférhet a liberális demokráciával, hiszen a semleges konszolidációhoz hasonlóan itt sem a hatalom növeléséről van szó alapvetően, hanem a környezethez való alkalmazkodásról. A hatalom birtokosaival szemben sokszor választói elvárás is, hogy a nemzetközi közösség támogatását kivívják, a társadalmi-gazdasági problémákat enyhítsék, vagy a civil szférában is legyenek aktívak, ezek mind-mind összeegyeztethetők a demokratikus alapelvekkel. Azonban itt is előfordulhatnak olyan lépések, amelyek áthágják a liberális demokrácia kereteit. Bizonyos gazdasági csoportokkal teljes szimbiózisban kormányozni (state capture, vagy lásd Lanskoy és MylesPrimakoff [2018] cikkét napjaink Oroszországáról), bár jelentősen javíthatja az újraválasztási esélyeket, egyes szereplőket indokolatlan privilégiumokhoz jut- 
tat, ezzel felülírva az egyenlőség alapvető követelményét. Nemzetközi, akár erőszakos beavatkozással fenntartani a hatalmat (pl. az 1956-os forradalom leverése) sem egyeztethető össze a liberális demokráciával. Ugyanígy, ha a civil szférában komoly és indokolatlan korlátozásokat szenvednek a kritikus szervezetek, mások pedig privilégiumokban részesülnek, az feltétlenül rontja a demokrácia minőségét, miközben elősegíti a hatalom beágyazódását. A külső beágyazás tehát történhet demokratikus és demokráciát erodáló módon is.

A belső beágyazás viszont szembemegy a jogállami normákkal, hiszen a független hatalmi központokat függővé teszi egymástól. Ez a hatalmi ágak elválasztását sértheti meg, amennyiben a különböző ágakat teszi egymástól függôvé a konszolidáló aktor, de akár egyetlen hatalmi ágon belül is problémás lehet különböző, eredetileg független szereplők vagy intézmények függési helyzetének kialakítása, így a belső beágyazás nem egyeztethető össze a liberális demokráciával.

Érdemes megvizsgálni a két párhuzamba állított fogalom, a hatalmi konszolidáció és a demokratikus konszolidáció egymáshoz való viszonyát is. Egyrészt intuitívan mondhatjuk, hogy a legtöbb esetben a két folyamat ellentétes irányba hat: a hatalmi konszolidáció jellemzően rontja a demokrácia minőségét, a demokratikus konszolidáció pedig (definíciója szerint) javítja azt. A demokratikus konszolidáció egyik fő célja valójában a hatalmi konszolidáció bizonyos formáinak megakadályozása intézményes korlátok felállításával. Elég csak a hatalmi ágak elválasztására gondolni, ami a demokratikus konszolidáció fontos eleme, a hatalmi konszolidációt pedig jelentősen megnehezíti. Amikor Schedler demokráciához hútlen aktorokról beszél, olyan szereplőkre gondol, akik hatalmi konszolidációt szándékoznak végrehajtani. A sikeres demokratikus konszolidáció tehát a hatalmi konszolidáció korlátok közé szorítását és bizonyos fajtáinak megszüntetését is magában foglalja. Fordítva ez egyáltalán nem igaz: a hatalmi konszolidációnak nem célja a demokratikus konszolidáció visszafordítása, ez legfeljebb eszköz lehet a hatalom megtartásához vagy növeléséhez. A hatalmat konszolidáló aktorok általában nem azt tartják szem előtt, hogy a rendszer milyen mértékben demokratikus, hanem azt, hogy mekkora hatalommal bírnak benne. Amennyiben a demokrácia megtartásával tudják növelni vagy megtartani a hatalmukat, akkor megmaradnak a demokratikus keretek, amennyiben viszont ezek akadályozzák a hatalmi konszolidációt, akkor, ha képesek rá, lebontják azokat.

Mint azt a fentiekben láthattuk, nem lehet a demokratikus konszolidáció célja a hatalmi konszolidáció minden típusának ellehetetlenítése. A hatalmi konszolidáció több fajtája is összeegyeztethető a liberális demokráciával, sőt, bizonyos esetekben elősegítheti a demokratikus konszolidációt. Az átmenet időszakában, amikor az ancien régime erői még nem gyengültek meg, fontos, hogy a demokratikus szereplők kiterjesszék a hatalmukat minél több olyan hatalmi térre, ahol a régi, demokráciát ellenző aktorok befolyása még számot- 
tevő. Például gyakran előfordul (Latin-Amerikára különösen jellemző), hogy hiába veszik át a politikai szférában a vezetést demokráciához hủ politikusok, a hadsereg vezetése továbbra is a régi, ez pedig magában hordozza a puccs veszélyét. A demokratikus konszolidáció fontos eleme ilyenkor, hogy a hadsereg is demokratikus kontroll alá kerüljön, ehhez pedig a demokratikus vezetőknek konszolidálniuk kell a hatalmukat, kiterjesztvén egy olyan területre, amelyre korábban nem volt komoly befolyásuk (pozitív konszolidáció). A demokratikus erők hatalmi beágyazása pedig sok esetben azt is jelenti, hogy a demokratikus beágyazódás is lezajlott: a nemzetközi, társadalmi-gazdasági és a civil környezet egyaránt a demokratikus játékosokat támogatja, ezzel biztosítván azt, hogy az autoriter aktorok nem kerülhetnek a hatalom közelébe, és a demokrácia fenntartható lesz (negatív konszolidáció).

A demokratikus és a hatalmi konszolidáció viszonya nem egyszerü fordított arányosság, tehát nem igaz az, hogy minél több sikeres hatalmi konszolidációt tapasztalunk egy országban, annál kevésbé konszolidált demokráciáról beszélhetünk. Fontos felismerni, hogy mely hatalmi konszolidációs lépések egyeztethetők össze a liberális demokrácia alapelveivel, és melyek nem, de nem lehet egyértelmúen kijelenteni, hogy azon szereplő, aki hatalmi konszolidációt kísérel meg, antidemokratikus lenne. A hatalmi konszolidáció jellemzően az átmeneti időszakban a demokratikus konszolidációt elősegíti, konszolidált demokráciákban viszont általában a demokrácia eróziójához járul hozzá.

\section{ÖSSZEGZÉS}

A tanulmány a hatalmi konszolidációt mint új, önálló fogalmat mutatta be. A fogalommal és a hozzá tartozó jelenségekkel a társadalomtudomány több ága is foglalkozott már, egységes, önálló fogalomként mégsem kezelte azt. Ezért a tanulmány a konszolidációval rokonítható fogalmak bemutatását követôen egy általános definíciót adott, valamint a hatalmi konszolidáció típusait is megkülönböztette a demokratikus konszolidációval vont párhuzam segítségével. Ez alapján a hatalmi konszolidáció során egy politikai aktor, aki hatalom birtokában van, arra használja hatalmi pozícióját, hogy hosszú távú hatalmát növelje, vagy legalább megőrizze azon a szinten, ami már rendelkezésére áll. Ennek típusai a negatív, a semleges és a pozitív konszolidáció, valamint a hatalom beágyazása. A típusok jellemzőinek ismertetése és példákkal illusztrálása után a hatalmi konszolidáció és a demokrácia viszonya zárta a tanulmányt. Ezen vizsgálat eredményeit foglalja össze az 1. táblázat.

A hatalmi konszolidáció itt bevezetett általános meghatározását és tipológiáját természetesen számtalan irányban tovább lehet gondolni. Egyrészt ez a keret a manapság a témában gyakori esettanulmányok esetében is hasznos lehet a különbözô konszolidációs lépések strukturált elemzésére, és empirikus 


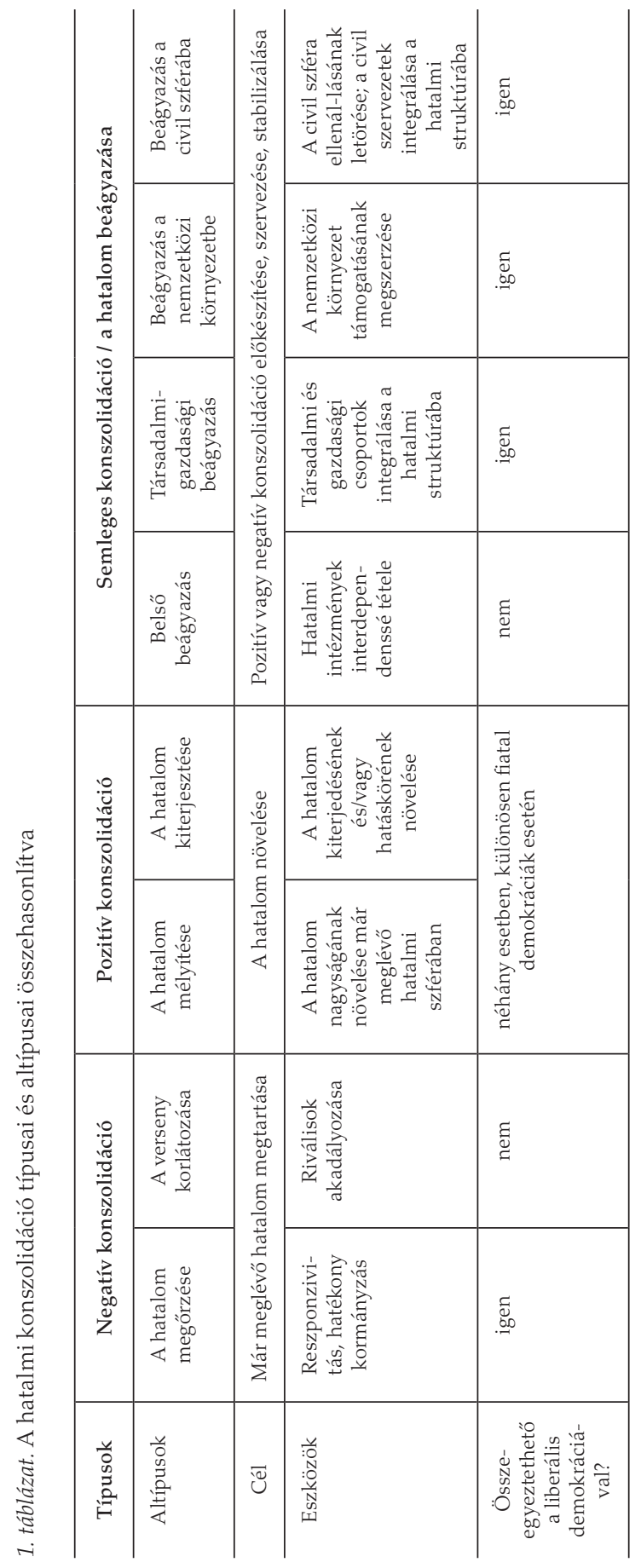


vizsgálatok esetén az operacionalizációban is segíthet. Másrészt a tipológia és a hatalom-felfogás módosításával több irányba is alakítható, bővíthető ez a leírás; akár olyan jelenségeket is a hatalmi konszolidációhoz lehet sorolni, amelyek ebben a tanulmányban nem minősültek annak. A tanulmány fő célja az volt, hogy egy manapság rendkívül gyakran elemzett jelenséghalmazt általánosan és elméletileg közelítsen meg; a hatalmi konszolidációval foglalkozó vizsgálatokat megkönnyítve és az ide tartozó jelenségekről folyó diskurzust új irányba terelve.

\section{JEGYZET}

1 Lásd pl. az Erdogan elleni puccskísérletre válaszként érkező tisztogatásokról szóló híradásokat (https://www.ft.com/content/aed570e6-a410-11e6-8b69-02899e8bd9d1), vagy a republikánusok észak-karolinai alkotmánymódosításai kapcsán születő cikkeket (https://www.washingtonpost.com/opinions/north-carolinas-jarring-gop-power-grab-feels-familiar/2016/12/ 20/50d530aa-c619-11e6-85b5-76616a33048d_story.html).

\section{IRODALOM}

Arendt, Hannah (1951): The Origins of Totalitarianism. New York, Harcourt, Brace \& Co.

Becker, Carmen (2006): Strategies of Power Consolidation in Syria Under Bashar al-Asad: Modernizing Control Over Resources. The Arab Studies Journal, Vol. 14, No. 1, 65-91.

Cheeseman, Nic - Gabrielle Lynch - Justin Willis (2017): Ghana: The Ebbing Problem of Incumbency. Journal of Democracy, Vol. 28, No. 2, 92-104. https://doi.org/10.1353/jod.2017.0027

Dahl, Robert A. (1961): Who Governs? New Haven, Yale University Press.

Dahl, Robert A. (1972): Modern Political Analysis. Second Edition. New Delhi, Prentice Hall.

Deutsch, Karl W. (1968): The Analysis of International Relations. Englewood Cliffs, Prentice Hall.

Epstein, Klaus (1962): The Nazi Consolidation of Power. The Journal of Modern History, Vol. 34, No.

1, 74-80. https://doi.org/10.1086/238998

Friedrich, Carl J. (1963): Man and his Government. New York, McGraw Hill.

Ginsburg, Tom (ed.) (2014): Constitutions in Authoritarian Regimes. Cambridge, Cambridge University Press.

Golder, Matt (2005): Democratic electoral systems around the world, 1946-2000. Electoral Studies, Vol. 24, No. 1, 103-121. https://doi.org/10.1016/j.electstud.2004.02.008

Landau, David (2013): Abusive Constitutionalism. UC Davis Law Review, Vol. 47, No. 1, 189-260.

Lanskoy, Miriam - Dylan Myles-Primakoff (2018): The Rise of Kleptocracy: Power and Plunder in Putin's Russia. Journal of Democracy, Vol. 29, No. 1, 76-85. https://doi.org/10.1353/jod.2018.0006 Levitsky, Steven - Lucan Way (2010): Competetive Authoritarianism: Hybrid Regimes After the Cold War. Cambridge, Cambridge University Press. https://doi.org/10.1017/cbo9780511781353 
Linz, Juan J. - Alfred Stepan (1996): Problems of Democratic Transition and Consolidation. Baltimore: Johns Hopkins University Press.

Mann, Michael (1984): The Autonomous Power of the State: Its Origins, Mechanisms and Results. European Journal of Sociology, Vol. 25, No. 2, 185-213. https://doi.org/10.1017/s0003975600004239

Merkel, Wolfgang (2004): Embedded and Defective Democracies. Democratization, Vol. 11, No. 5, 33-58. https://doi.org/10.1080/13510340412331304598

Milton-Edwards, Beverley (2008): The Ascendance of Political Islam: Hamas and Consolidation in the Gaza Strip. Third World Quarterly, Vol.29, No. 8, 1585-1599. https://doi.org/10.1080/01436590802528739

Mulgan, Aurelia George (2018): The Abe Administration and the Rise of the Prime Ministerial Executive. London - New York, Routledge. https://doi.org/10.4324/9781315101736

Parsons, Talcott (1963): On the Concept of Influence. Public Opinion Quarterly, Vol. 27, No. 1, 37-62. https://doi.org/10.1086/267148

Poguntke, Thomas - Paul Webb (2005): The Presidentialization of Politics: A Comparative Study of Modern Democracies. Oxford, Oxford University Press. https://doi.org/10.1093/0199252017.001.0001

Sartori, Giovanni (1976): Parties and Party Systems: A Framework for Analysis. Cambridge, Cambridge University Press.

Schedler, Andreas (1998): What is Democratic Consolidation? Journal of Democracy, Vol. 9, No. 2, 91-107. https://doi.org/10.1353/jod.1998.0030

Schedler, Andreas (2001): Measuring Democratic Consolidation. Studies in Comparative International Development, Vol. 36, No. 1, 66-92. https://doi.org/10.1007/bf02687585

Schedler, Andreas (ed.) (2006): Electoral Authoritarianism. The Dynamics of Unfree Competition. Boulder-London, Lynne Rienner Publishers.

Tanasescu, Gabriela (2014): Romania and Russia: Cases of Semi-Presidentialism. The Problem of Presidentialization. Romanian Review of Political Sciences and International Relations, Vol. 11, No. 2, 77-88.

Thornhill, Michael T. (2004): Britain, the United States and the Rise of an Egyptian Leader: The Politics and Diplomacy of Nasser's Consolidation of Power, 1952-4. The English Historical Review, Vol. 119, No. 483, 892-921. https://doi.org/10.1093/ehr/119.483.892

Tilly, Charles (1975): The Formation of Nation States in Western Europe. Princeton, Princeton University Press.

Turner, Jonathan H. (2004): Toward a General Sociological Theory of the Economy. Sociological Theory, Vol. 22, No. 2, 229-246. https://doi.org/10.1111/j.0735-2751.2004.00214.x

Tushnet, Mark (2015): Authoritarian Constitutionalism. Cornell Law Review, Vol. 100, No. 2, 393461.

Vanhanen, Tatu (2000): A New Dataset for Measuring Democracy, 1810-1998. Journal of Peace Research, Vol. 37, No. 2, 251-265. https://doi.org/10.1177/0022343300037002008 